\title{
The Protection of Minorities - Whether a Neglected Field?
}

\author{
By Kamal Ahmad Khan*
}

\begin{abstract}
Minorities are existing socio cultural realities. The protection of minorities is the hallmark of a civilized nation. The claim of a country to civilization depends on the treatment it provides to the minorities. The most certain test by which we may judge whether a country is really free is the amount of security provided to the minorities. The minority problem has led to intervention, aggression and major conflicts between states. The relation between dominant and non dominant cultural, religious and linguistic groups within a political system has been a perennial problem of politics since time immemorial. In the past it was symbolized by the conflict between dominant and non dominant religious groups. Knowledge was power in ancient Egypt, Greece, Rome, Persia, India and China. Knowledge as power was in the hands of a small minority. The problem of minority as we know it today did not arise in those days. Minorities exercised power and very often the majority had to submit to the minority. It was hoped that the problem will get resolved with separation of Church and State. The rise of secularism associated with the rise of nationalism further aggravated this problem by advocating the concept that the political boundaries should confirm to the national characteristics of the people. Most of the States regarded themselves as a power instrument of the dominant group. States tried to mould the people belonging to minorities in accordance with the religious, linguistic and cultural traits of majority through education, propaganda, political and legal action. Where the minority group resisted this policy, States resorted to extermination and expulsion of the minorities to assure national uniformity. The problems of minorities have attracted both national and international attention. But in spite of different efforts the problem has so far been neglected either knowingly or unknowingly. The area may be summarized as issues of definition of the term minorities and contradictory provisions of different international instruments. However, in this background the purpose of this paper is to deal with different aspects of the concept of the term minorities and to evaluate and analyse both national and international instruments to protect the minorities. ${ }^{l}$
\end{abstract}

Keywords: Concept of minority, International Treaties, Human Rights, Neglected field, Will of the States and Mind set of the authorities.

\footnotetext{
*Associate Professor, Faculty of Law, University of Lucknow, India.

${ }^{1}$ I am thankful to the Almighty "Allaha" for enabling me to write this work. I am equally thankful to writers of past who laid down the key stone for the present work. I am thankful to my teacher Professor R. R. Lyall for his guidance and my colleagues Dr. R.K. Verma, Dr. R.K. Singh and Dr. Ashish Kumar Srivastava for proof reading and formatting. I express my sincere gratitude to my family, specially to my parents.
} 


\section{Introduction}

The problem of minority as we know it today is related with the concept of democracy which replaced the personal rule or group rule of a class. The consensus of opinion, the will of the majority dominated the system of the government. It was only when a community became conscious that all members of a community have certain functions, duties and certain rights, the question of minorities attained an increased importance. ${ }^{1}$ Inseparable from the rights is their guarantee, legal or political. Legal guarantees are found in treaties, constitutions, and in laws. Political guarantees are found in the structure of the state, in political parties and in electoral systems. The constitution is not in itself a guarantee but the guarantee lies behind the constitution i.e. the judicial system which involves the whole political system. On the other hand, the political guarantee which does not give rights but powers includes structure of the state, the electoral system, and even political parties. The protection of minorities lies in the fact that how much minorities are involved in the system of the government and how the system responds to their demands.

The slogan, after the First World War was the protection of minorities, after the World War II the slogan was changed and emphasis was given to the protection from minorities and rather to abolish the problem by adopting certain means.

\section{League of Nations and Minorities}

No general provisions for the protection of minorities applicable to all states were instituted under the League of Nations Covenant. Millions of citizens whose native language was not Polish, Czech, or Rumanian were allocated by the Peace Treaties to Poland, Czechoslovakia, newly constructed States like Yugoslavia and Rumania. This fact strengthened the conviction among the major allies that something would have to be done to protect the rights of these minorities. States like Austria, Bulgaria, Czechoslovakia, Greece, Hungary, Poland, Rumania and Yugoslavia were put under some sort of treaty obligation, though their democratic institutions were not yet fully trusted. The American government on the suggestion of American Jewish organization entered into a treaty with Poland to serve as model for similar treaties with other states concerned. But Rumania, the principal allies encountered great difficulties before being able to persuade the new authorities to agree to treaties which conferred nothing but elementary justice.

Czechoslovakia signed a minority treaty on the Polish pattern but was reluctant to have any provision singling out the Jews as needing special protection.

Furthermore, unilateral declarations on the lines of the Polish Treaty were made to the Council of the League of Nations by Albania, Estonia, Iraq, Latvia

\footnotetext{
1 Kabir (1968) p. 2.
} 
and Lithuania. But States like Belgium and Italy were not included in the treaty, though they had ethnic minorities after the First World War. Thus the lack of universality of the system was the main criticism levelled against the way of the protection of minorities under the League of Nations. ${ }^{1}$ The fate of undertaking of 1919 concerning minorities under Peace Treaties was put in dilemma after the Second World War ${ }^{2}$, but a few authors dealing with the question of validity of the Peace Treaties are in disagreement with the UN document as to when and how the undertaking of 1919 ceased to be valid. ${ }^{3}$ Modeen ${ }^{4}$ emphasizes that the United Nations is clearly not concerned to take over the responsibility for the fulfilment of any minority treaties from the post World War 1 period. Neither the agreements concerning Turkey and Greece or the Aaland Islands (Finland) nor the United Nations considered the declarations made to the League of Nations by Albania and Iraq as binding. The Treaty of Friendship and Assistance between Yugoslavia, Greece and Turkey (1953) and the Treaty of Military Alliance among these States (1954) lost their effect through changes in the political situation. ${ }^{5}$ Only the Hungarian Government made an attempt to protect from discrimination and expulsion of the Hungarian living in Slovakia expressed the opinion that the minority's treaties were still valid. The study published by General Secretary of United Nations was for some years on the agenda of the United Nations Commission on Human Rights and it's Sub-Commission for the Prevention of Discrimination and Protection of Minorities but it was never discussed and eventually the matter was dropped entirely without giving any reason given. ${ }^{6}$

\section{Minority Treaties and its Effect}

The Minority Treaties established the minority States apart from ensuring protection against negative discrimination but the States were not obliged to take positive steps necessary for the preservation of the minority's ethnic character and traditions together with its national physiognomy. As a rule minority members were given only certain defined rights. States retained undiminished their sovereignty over their inhabitants. The ambiguously formulated minority treaties to provide a workable safeguard failed to provide for the existence of an actual minority in the relevant States. ${ }^{7}$ A little importance was given to local situations. Certain minorities were favored with autonomous rights for no apparent reason while more other significant were left with lesser rights. ${ }^{8}$

\footnotetext{
${ }^{1}$ Chandra (1985) p.125.

${ }^{2}$ United Nations Document E/CN, 4/367 of April 7, 1950 and E/CN, 4/367 Add.1, March 27, 1951.

${ }^{3}$ Modeen (1969) p. 71.

${ }^{4}$ Ibid. p.73.

5 Documents On International Affairs 1953 p. 221-223

${ }^{6}$ Chandra (1985) p. 126.

${ }^{7}$ Modeen (1969), p. 64.

${ }^{8}$ Kunz (1954) p.255.
} 
Besides this, the treaties were also left open the question of whether subjective or objective criteria should be applied in decisions affecting membership of a minority. They did not consider whether the actual existence of national or religious minorities or the will of a specific population group to preserve its own national or religious characteristics should be the decisive factor. Someone may consider language as decisive or one may depend upon the 'Will' of individual to belong or not to belong to the minority.

\section{Confusion}

The minority treaties were not clear on major issues namely whether the guarantee for the observance of the treaties were to be considered as generally forcing the league to continually exercise control over the minority states or whether the League had only to concern itself with breaches of the treaties brought before it. ${ }^{1}$

\section{No Effective Weapon}

League of Nations was not a supreme State organization but was merely an international body. Persuasion and mediation was the League's main weapon. Generally Council members were least bother about minority disputes and its formalist approach and the guaranteed system provided in the minority treaties was ineffective.

\section{Weak Shield}

The defective system for protection of minorities proved to be an ineffective shield to minorities. The political revolution in Europe caused break down of the system. Particularly Germany succeeded in inciting discontent among German minorities in various States. The unilateral revocation of the Treaty in 1934 by Poland caused hindrance in the progress and development of minority protection.

\section{Misinterpretation of Potsdam Agreement}

The agreement entered into on August 2, 1945 accelerated the transfer of population after the end of the Second World War. It is important to mention here that the agreement did not authorize the three governments of the victorious powers in question to remove the German populations from their territories. It mentioned only "the transfer of German population or element thereof, remaining in Poland, Czechoslovakia and Hungry." Hence the assumption of the United Nations study shows that in the Potsdam Declaration it was decided "that the German minorities should and could be transferred to Germany," does not correspond to the facts. It was nowhere mentioned in which cases "German populations" and in which cases "element thereof' should and could be transferred. It cannot be inferred that the remaining German population forfeited their right to be protected because they had been outlawed. Even if it would have been agreed to transfer all Germans from three states to Germany, this could never mean that the Governments in question

\footnotetext{
${ }^{1}$ League of Nations, Official Journal, Special Supplement, No.73, p.62
} 
were entitled to stipulate that members of minorities who had not been transferred "should no longer benefit from an exceptional regime."1

\section{Validity of Expulsion of Minorities}

The question arises whether the expulsion of national minorities after the Second World War was consistent with international law. Article 8 of the Polish Minority Treaty provides that the Polish nationals who belong to racial, religious or linguistic minorities should enjoy the same treatment and security as the other Polish nationals. The same provision was contained in the Minority Treaty signed by Czechoslovakia and the Trianon Peace Treaty with Hungry. There is no reason to assume that the minority's treaties had all lost its validity in 1945-46. In the resolution of United Nations General Assembly of Feb.12, $1946^{2}$, it was decided to take over certain functions and activities previously conducted by the League of Nations but it did not include the minority treaties though the League of Nations existed till April 1946 i.e. the same time after the beginning of the various acts of expulsion of minorities. The controversial question whether the dissolution of the League of Nations brought about the automatic laps of the guarantee contained in the minority treaties or of these treaties themselves was answered in the negative by the advisory opinion of the International Court of Justice on the International Status of the South West Africa. ${ }^{3}$

\section{Peace Treaties and Minorities}

\section{No Direct Protection Clause}

The Peace Treaties of Feb.10, 1947 contain no clause concerning the direct protection of national or other minorities. The treaty emphasized only on individual human rights without distinction as to language and in the case of Hungarian and Rumanian treaties, it forbid discrimination among citizen including linguistic discrimination. Hungary's efforts at the Paris Peace Conference to secure regulations for the protection of Minorities were unsuccessful. ${ }^{4}$

The crucial demand of Hungry for frontier revisions with Czechoslovakia and Rumania in order to reunite Magyars with their mother-state was also rejected and the Hungarian minority in Czechoslovakia was compelled to migrate to Hungary. ${ }^{5}$

\section{No Specific Minority}

With exception of Hungarian Minority in Czechoslovakia together with clauses in the Italian Treaty containing a reference to special treaties

\footnotetext{
1 Modeen (1969), p. 68.

${ }^{2}$ U N General Assembly Resolution, 24 (1)

3 U N Document E/C N 4/367 Add, March 27, 1951

${ }^{4}$ Bagley (1950) p.201.

5 Claude (1995) p.120.
} 
concerning Trieste and South Tyrol, the treaties do not recognize the presence of any specific minority to which protection should be guaranteed. ${ }^{1}$

Thus the treaties grant to no minority any right comparable to those prevailing under the post-first World War agreements. There are no statutory rights for the education of minority groups in their own language or for the use of their own tongue in the courts or other public institutions. The States were not obliged to take positive steps to protect rights of the minorities and to prohibit discrimination among inhabitants.

\section{Weaker Guarantee}

The Treaty of March 10, 1947 between Poland and Czechoslovakia provides weaker guarantees for the protection of minorities. Only the Trieste Treaty establishes a special arbitration body before which complaints may be heard. The inhabitants of Trieste have thus retained a 'locus standi' before an international organ which has no right to pronounce binding judgments but is only a mediator body. The Austrian State Treaty like the South Tyrol Treaty, bases the fulfilment of measures of protection only on the interest of the parent states concerned. Obviously the United Nations is competent to discuss problems arising out of the application of all these treaties but it has not been expressly taken the position of a guarantor for the implementation of the treaties $^{2}$

Thus the international guarantee for the currently valid minority protection treaties is extremely unsatisfying.

\section{United Nations Organization and Minorities}

\section{Different Outlook}

The conflict between the West and the East largely paralyzed the activities of the United Nations in the field of the protection of minorities. The situation was aggravated by further differences in their outlook. Some countries opposed the protection as they wanted quick assimilation of the new comers. The situation has been briefly characterized by one of the writers dealing with this problem after the Second World War. ${ }^{3}$

\section{Defective Charter}

The minorities of any category and the necessity to protect them on an international level are not mentioned in the charter. This was also not done by the League Covenant. Even then a system was established with in the League for checking whether and how the various states lived up to their commitments for Unilateral Declarations. A broader notion can be seen when the Economic and Social Council included into the terms of reference of the newly created

\footnotetext{
${ }^{1}$ Jones (1949) p.599.

${ }^{2}$ Modeen (1969) p. 94

${ }^{3}$ Claud (1955) p. 152
} 
Commission on Human Rights for the protection of minorities in general and not for specific minorities.

\section{Terms Not Defined}

Originally it was planned to set up two Sub- Commissions on the Commission on Human Rights. One dealing with the prevention of discrimination and the other with the protection of minorities. The Commission on Human Rights decided, to establish only one Sub- Commission for both the problems. ${ }^{1}$ The Sub- Commission was entrusted to make recommendations to the Commission on Human Rights concerning the prevention of discrimination of any kind relating to human rights and fundamental freedoms and the protection of minorities. ${ }^{2}$ Within the United Nations the terms "prevention of discrimination" and "protection of minorities" have never been defined in a way acceptable to the bodies taking binding decisions. The shortest formula adopted by the Secretariat was that the prevention of discrimination was related to 'the implementation of the principle of equality of treatment', and protection of minorities was named protection against undesired assimilation.'

\section{No State Obligation}

In the beginning there was some eagerness to include positive measures for the protection of national minorities into an envisaged International Convention on Human Rights. The draft outline of an International Bill of Rights prepared by the United Nations Secretariat in 1947 contained the following proposal: ${ }^{3}$

"In States inhabited by substantial number of persons of race, language or religion other than those of the majority of the population, persons belonging to such ethnic, linguistic or religious minorities shall have the right to establish and maintain out of an equitable proportion of any public funds available for the purpose, their schools and cultural and religious institutions, and to use their own language before the courts and other authorities and organs of the State and in the press and in the public assembly."

Professor Rene Cassin submitted amendment suggesting the deletion of the words that schools and cultural institutions should be maintained "out of an equitable proportion of any public funds available for the purpose." After long deliberations the whole idea was dropped in the Sub-Commission and in the Commission on Human Rights.

\section{Little Importance Attached to Minority Protection}

How little importance the United Nations attached to the question of international protection of national minorities is shown by the fact that the

\footnotetext{
${ }^{1}$ Year Book of the United Nations, 1946/1947, New York, 1947, p. 328

2 Noted by the Secretary General, Nov.6, 1958 E/CN, 4/ Sub 2/194, p.6

${ }^{3}$ U N. Document A/CN. A/CN. 4/A/C 1/3.
} 
matter has been relegated to a mere Sub- Commission composed of experts and not of representatives of States, nominated by the States. Nearly half of the present members have to be citizens of the "Afro-Asian Group of States."1

\section{Lack of Positive Protection}

As the members of Sub-Commission are not interested in positive steps to protect ethnic minorities, their participation in United Nations task hardly expedite the work of the Sub-Commission. The proposals of the SubCommission did not find the approval of the Commission on Human Rights and of the Economic and Social Council. ${ }^{2}$ A proposal of the Sub-Commission made in 1951 on Interim Measures for the protection of minorities dealing with the use of minority language in courts etc. and the education in minority language was not even considered. ${ }^{3}$

\section{Genocide Convention 1948 and Minorities}

The problem of a special minority protection was again under discussion when the Convention on the Prevention and Punishment of the Crime of Genocide was debated within the various United Nations Organs.

\section{No Protection against Cultural Genocide}

The Convention of 1948 did nothing to protect minorities from measures designed to undermine or destroy their cultural or linguistic attributes. ${ }^{4}$ The draft convention prepared by the Secretariat introduced the notion of 'physical genocide' and 'biological genocide', instead of 'cultural genocide' with the following formula:

"In this Convention genocide means any deliberate act committed with the intent to destroy the language, religion or culture of national, racial or religious group on grounds of the national, racial or religious group on grounds of the national or racial origin or religious belief of its members such as:

Prohibiting the use of the language of the group in daily intercourse or in schools or the printing and circulation of publications in the language of the group,

\footnotetext{
${ }^{1}$ The Sub-Commission had in the beginning twelve and later eighteen members. In 1968 the membership was enlarged to twenty six. ECOSOC Resolution 1334(XLIV) May 31, 1968, which at the time laid down rules for the territorial distribution of membership in order to secure an appropriate representation of the "new" UN members: Afro-Asian Group of States 12, Western European and other States 6, Latin America 5, Eastern European States 3.

${ }^{2}$ Claud (1951) p. 300

${ }^{3}$ Resolution III in Annex 1 to E/CN. 4/641 (Report of the Fourth Session of the SubCommission).

${ }^{4}$ Thornberry (1980) p.444.
} 
Destroying or preventing the use of libraries, museums, schools and historical monuments, places of worship or other cultural institutions and objects of the group."

The Soviet Union(Russia) supported by Czechoslovakia and Poland pleaded for the retention of this provision in the final text of the convention while the USA advocated the opposite view point mentioning that the matter ought to be dealt with in a different context. ${ }^{1}$ This argument was used many times inside the United Nations, whenever suggestions were made to take active steps for the protection of minorities. Claud summed up the situation in the following words: "whether the issue is presented it is out of place; whenever it is presented, it is premature."

Ultimately the reference to cultural genocide was deleted from the convention, and thus the United Nations declined to give official support to the concept of positive minorities rights. ${ }^{3}$

\section{No Guarantee to the Existence of State}

The Genocide Convention guarantees the right of continued existence to members of minorities; it does not guarantee the continued existence of a group discrete entity. In the case of Bosnia and Herzegovina v. Yugoslavia (Serbia and Montenegro) ${ }^{4}$ the International Court of Justice opined that the Genocide Convention does not guarantee the continued existence of particular state. The Court noted that the essential characteristics of the definition of genocide was "the intended destruction of a national, ethnical, racial or religious group" and not the disappearance of a state as a subject of international law or a change in its convention or its territory.

\section{No Penal Tribunal}

The Convention on Genocide may be characterized as means of protecting minorities but in reality it is mostly concerned with the protection for population groups in minority positions. The Convention instead of working positively for the recognition of minority, rather concentrates negatively on the punishment of criminal act directed against the group. The aim of the Convention is to give the minorities the right to live but not to give them the right to live as minorities. ${ }^{5}$

The UN has not established an effective International Penal Tribunal for such crime of genocide ${ }^{6}$. Recently an International Criminal Court has been established though it has no teeth to bite the violating States. It is also important to mention that the States are not under legal obligation to bring the matter before the Court.

\footnotetext{
${ }^{1} \mathrm{~A} / \mathrm{PV}, 1 / 18$ and 179 , for a discussion in the General Assembly.

${ }^{2}$ Claud (1955) p. 164

${ }^{3}$ Ibid. p. 155

${ }^{4}(1994) 95$ ILR, 1.

${ }^{5}$ Laponce (1960) p. 34.

${ }^{6}$ Oppenheim \& Lauterpacht (1960) p.751.
} 


\section{Universal Declaration of Human Right 1948 and the Minorities}

This declaration ${ }^{1}$ provides a general right to all persons of the world. There is no specific mention of minority rights. The General Assembly expressly rejected a proposal to include a clause for the protection of minorities in the declaration. The declaration includes a clause only against discrimination without recognizing the need for positive protection for minorities. ${ }^{2}$ The suggestion of Sub- Commission on Human Rights to omit from the text of the Declaration all references of minorities was upheld by Third Committee of the 1948 Generally Assembly, where Mrs. Eleanor Roosevelt, the US representative argued that it was impossible to deal in the Declaration with a problem which in actual fact only covers the continent of Europe. ${ }^{3}$ The tale of Russia (Soviet Union) is different. It is surprising that in the first decade of the existence of United Nations it posed as a champion of minority rights but it refused to feel bound by any international measure for protection of human rights. The real Soviet approach to the problem can be found in the definition given by the Soviet representative to the1948 General Assembly's Third Committee. ${ }^{4}$ However, the declaration remains only an international ethical norm of conduct. The United Nations could not deal in specific provision with the question of minorities in the text of this declaration. ${ }^{5}$ Thus the United Nations could neither influence member states to agree to the protection of minorities nor has been proved to be an effective instrument for correcting even the most flagrant assault upon elementary human rights with in its member- States. ${ }^{6}$

\section{Article 27 of the ICCPR and Minorities}

The Sub-Commission 1955-1968 did not devote any attention to the question of minorities. Edward Schiller (Austria) pressed at the $21^{\text {st }}$ session of the Sub-Commission (1968) for the resumption of the work on protection of minorities. Consequently the matter was put on the agenda of the $22^{\text {nd }}$ (1969) and $23^{\text {rd }}$ session (1970) but never reached an end due to the lack of time. ${ }^{7}$

\section{No Positive Duty}

Article 27 of the International Covenant on Civil Political Rights does not put governments under positive duty to promote minority culture, language, or

\footnotetext{
1 The Declaration is included in the Year Book on Human Rights for 1948, p.466

${ }^{2}$ Modeen (1969) p. 104

${ }^{3}$ A/C3/SR 161, November 27, 1948

4 A / C 3/S R 154

5 An analysis containing a critical view of the General Assembly's restrictive stand point given given by Bagley (1950) p.145

6 Brierly (1963) p. 188.

${ }^{7}$ E/CN. 4/917, 1008 and 1040
} 
religion. ${ }^{1}$ The obligation contained in Article 27 consists simply of a duty not to interfere in enjoyment of their right.

\section{No Uniform Solution}

The application set forth in Article 27 of the Covenant is an extremely complex matter which does not admit a uniform solution ${ }^{2}$. It should be put into effect wherever religious or linguistic minorities exists. The difficulty arises on the issue that what groups constitute minorities? A few States expressly recognize the existence in their populations of groups described as "ethnic or linguistic minorities while the other States have introduced measures granting special rights to various ethnic and linguistic groups and the majority prefers not to apply the term "minorities" to them. The scope of measures also varies from country to country and group to group. There is persisting wariness of any international system for the protection of minorities. Hence some general criteria for the application of Article 27 are needed. In this connection, the observations of participants in the seminar are worth mentioning. "[...] though the basic principles of respect for human rights were applicable to members of all minorities, the variety of the historical and socio-economic condition under which minorities had been formed and developed in various regions of the world might require a diversified approach to the problem of the protection and promotion of their human rights."3

\section{Problem of Definition}

A definition would certainly be of great value on the doctrinal plane but it should not be considered a precondition for the application of the Covenant. It may be noted that the General Assembly did not wait for an exhaustive and universal definition of the notion of 'the rights of the people to self determination' before proclaiming the application of the principle. Besides this numerous international instruments have used different terminologies for protection of the rights of certain groups of population to preserve their culture and use their own language. Similarly under municipal law States have used more varied terminology to refer to groups of population for protecting their culture and language by the law or the Constitution. Belgium used the term cultural communities, Rumania refers co-inhabiting nationalities and Eastern Europe uses only nationalities. In other countries the strait forward term minority is used. But one cannot shut one's eyes to the practical problem relating to the term minorities. The opening clause of the Article 27 reads: "In those States in which ethnic religious or linguistic minorities exist [...]." Some States have interpreted this clause to mean that they themselves may determine whether or not there exists any minority group within their borders.

\footnotetext{
${ }^{1}$ Thornberry (1980) p. 449.

${ }^{2}$ Ansari (1996) p. 258.

${ }^{3}$ Seminar on Protection of the Human Rights of National, Ethnic and Other Minorities, Ohrid, Ohrid, Yugoslavia,25 June-8 July, 1974, (ST/TAO)HR/49) para. 22.
} 


\section{Criterion of the Definition Confusing}

There are mainly two criterions i.e. subjective and the objective to define the term minority. The objective criterion emphasizes:

That the distinct group posses' stable ethnic, religious or linguistic characteristics,

That the group must in principle be numerically inferior to the rest of the population,

That the group should be in non dominant position and lastly,

That the distinct group must have juridical status i.e. national of the State.

The subjective criterion is the "will" on the part of the members of the groups in question to preserve their own characteristics. This subjective criterion provides an opportunity to the State to refuse protection by claiming that the group themselves do not intend to preserve their identity.

\section{Inadequate Protection}

The protection of minorities is not adequate. Most of the instruments relating to the protection of minorities emphasizes either on the principle of "equality" or on the principle of "non discrimination". The concept of equality and non discrimination imply formal guarantee of uniform treatment for all individuals whereas protection on minorities imply special measures in favour of members of a minority group. The positive measures by State are also necessary to protect the identity of a minority, to develop their culture, language and religion whereas the Article 27 uses the words: "persons belonging to minorities shall not be denied the right $[\ldots]$ to enjoy their own culture [...]." The use of the words "shall not be denied" means that States and governments are not obliged to take positive measures, involving administrative action or financial support. Similarly, the rights relating to culture have been regarded as referring to members of ethnic minorities and right to use of language as referring linguistic minorities, if minority is both ethnic and linguistic its members should enjoy both categories of right.

\section{The Protection of Language - A Myth}

Language is the key to all intellectual and a great part of spiritual life. ${ }^{1} \mathrm{~A}$ common language alone makes free and familiar intercourse between two human beings and creates a bond between them. Its choice of words, turn of phrase, very idiom and peculiarity, is a sort of philosophy which expresses the past history, character and psychological identity of those accustomed to use it. The loss of language is a part of the more general loss being suffered by the world and the loss of diversity in all things. What is guaranteed to minorities is merely the right to use their own culture and language to profess their religion although; the kind of religion, language and culture that is protected has not

\footnotetext{
${ }^{1}$ Macartney (1968).
} 
been fully clarified. It is also not clear that how States are to identify religious, linguistic and cultural groups. The obligation imposed on States with respect to protection of minority language by International Covenant on Civil and Political Rights and ECHR, Copenhagen Declaration etc. can be seen as a limited attempt to redress a gap in the UN Convention on Prevention and Punishment of the Crime of Genocide. ${ }^{1}$ Similarly, the Framework Convention mentions binding legal obligations but it was clouded by the proviso that this guarantee is subject to the measures taken by the states in pursuance of their general integration policy. This Convention is not concerned with communication with public authorities or the use of the minority language in official context. Minority language education is necessary to maintain their identity by acquiring proper knowledge of their mother tongue. The right to set up schools without any guarantee of state support is hallow right in the context of minority language communities which are generally economically weak and vulnerable. The provisions relating to right of minorities in decision making affecting them have only persuasive force in states. Whether it may be Article 2(3), 5 ( 1 ) of UNGA Minorities Declaration, Article 33 and 35 of the Copenhagen Declaration, Article 11 of the Minorities Protocol or even the Minority Language Charter imposes no significant requirement to involve the minority language community in decision-making and linguistic planning process.

\section{Personal Law}

There is general tendency to apply a uniform set of rules throughout the country with respect to the preservation of legal traditions of minority groups. However, in countries in which political autonomy has been granted in areas where a minority group is concentrated, matters of private law are often within the competence of the local legislature. There cannot be any doubt that an effective and full protection of the culture of minorities would require the preservation of their customs and legal traditions which form an integral part of their way of life. However, the maintenance of judicial institutions among minority groups ought to be conditioned by the state legislative policy.

\section{Misconceptions about Minority Rights}

With the perusal of various deliberations and minutes of the United nations bodies, it is found that majority of the members regard minority rights as something which should be interpreted as restrictively as possible and to be conceded only hesitatively. This was stated by the Sub-Commission differentiating between those rights demanded by minorities which are desired by all human beings and are covered by the Charter on the one hand and other

\footnotetext{
${ }^{1}$ Dunbar (2001).
} 
considerations of minorities on the other hand. ${ }^{1}$ The right to preserve ethnic relations or linguistic traditions or characteristics different from those of the rest of the population is by contrast and exceptional right. Equality in law precludes discrimination of any kind whereas equality in fact may involve the necessity of different treatment in order to attain a desired result which establishes equality between different situations.

\section{Requirement of Loyality - An Excuse}

In most of the United Nations deliberations the emphasis was given that the loyalty of the minority to the state where they live should be a precondition for granting protection to them.

In this connection the following questions may be raised:

(a) Why should members of a minority have to prove a higher sense of loyalty towards the state?

(b)Who is going to decide whether the degree of loyalty shown by minorities is sufficient to qualify them for enjoyment of minority rights?

(c)Is the protection to the minority is a charity or a reward for their good behaviour?

(d)Is there any standard or formula laid down by the world community to weigh the loyalty and disloyalty of the minority community?

(e) Is it not the duty of the State to create an atmosphere in which the minority may develop loyalty to the State?

The questions mentioned above find support in the answer of Philippines representative in the Third Committee of the UN General Assembly in the year 1953: "[...] a state was entitled to protect itself against overt act of treason, sedition or rebellion, but those were acts which anyone could commit irrespective of membership of an ethnic religious or linguistic group [...]." Minorities are not well organized bodies with collective responsibility.

The one sided condition of loyalty not counter balanced by any corresponding obligation incumbent upon the state in question is not only wrong in principle but it is even apt to nullify all positive provisions in favour of minorities.

\section{Conclusion}

On the basis of above study we may conclude that despite of several efforts both at the national and international level to protect the minorities, there are certain areas which need further protection. Whatever protections

\footnotetext{
${ }^{1} \mathrm{U}$ N Document E/C N. 4/641, p. 32.

${ }^{2}$ A/C. 3/SR.401,E/CN. 4/AC, 11/SR, 7.
} 
have been ensured to them must be followed in letter and spirit. A single member of the minority should enjoy unimpaired civil right as the majority members. They should have opportunities like the majority to develop political rights and to be appointed in the public service. Protection against discrimination is not enough. There must be some positive safeguards also. The minorities should have right to plead the minority cause both internally and before international law. The school is to a language what the Church to a religion -the condition of survival. Right to teach is negative guarantee i.e. without interference from the Government whereas right to be taught involves positive action. The Government should assume the financial burden of teaching minority language in the states' schools, or at least to subsidize the school of minority. Right to establish educational institution of their choice is not enough, the school should be in a position to give insight into the minority culture and not merely to give the majority point of view. The schools should be free from governmental interference in respect their syllabus, management and appointment of staff. State should take care of the economic capability of the area of minority settlements. The migration of majority members to the minority area should be restricted, industrial development, trade, agriculture and forestry in minority area should be developed. The political guarantee which gives power is found in the structure of the state, political system and in the electoral systems. A monocultural government should not be imposed on multicultural society. Reservation of seats in Parliaments and the Cabinet for minorities though undemocratic is necessary for existence of a democracy in a plural society. The State generally restrict the minority to have political power by influencing the general election by several methods including changing or dividing the constituencies inhabited by minorities through delimitation commission. Hence care should be taken at the international level to curb such tendencies. The numerical requirement for rights to the minorities must be fixed by law. They should be defined in both percentage and absolute figures. Dress and language reflect culture and identity of a group or community. Therefore, minorities should be assured to wear the dress of their group. Their language should be linked with economy of the country because language loses its importance and popularity when it loses its economic value. Fear plays an important role in human life. The protection of minority should be judged on the basis of intensity of fear prevalent among minority in respect of security of their life, liberty, culture and property. Therefore, making provisions and declarations for the protection of minorities is not sufficient. A good provision may be a bad provision if the persons working behind them are of a bad lot. The real protection of minorities lies in the attitude and the mind set not only of the member states but also of the persons involved in implementing the provisions. The presence of minority is a social reality. Hate begets hate and love begets love. 


\section{References}

Ansari , I. A. (1996). Readings On Minorities, I O S, New Delhi, Vol. 1.,

Bagley, T.H. (1950).General Principles and Problems on The Protection of Minorities, Geneva .

Brierly, J.L (1963). The Law of Nations, $6^{\text {th }}$ Edition, Oxford.

Chandra, S. (1985). Minorities in National and International Laws, New Delhi.

Claud, I.L. (1955). National Minorities-International Problem, Cambridge.

Claud, L.L. (1951). The Nature and Status of the Sub-Commission on Prevention of Discrimination and Protection of Minorities, International Organization, Vol. 5, Boston.

Documents On International Affairs 1953, London 1955, p. 221-223

Dunbar, R. 'Minority Language Rights in International Law, I C Q, Vol. 50, 2001E/CN. 4/917, 1008 and 1040

Jones, M. G. (1949). National Minorities, A case Study in International Protection, Law and Contemporary Problems.

Kabir, H. (1968). Minorities in a Democracy, Srinagar.

Kunz, J. L. (1954). The Present States of the International Law for the Protection of Minorities, AJIL.

Laponce, J. A. (1960). The Protection of Minorities, University of California Press.

League of Nations, Official Journal, Special Supplement, No.73, p.62

Macartney, C A. (1968). National States and National Minorities, New York, Russell and Russell.

Modeen, T. (1969). The International Protection of National Minorities in Europe, ABO (Finland).

Notes by the Secretary General, Nov.6, 1958 E/CN, 4/ Sub 2/194, p.6

Oppenheim, L. (ed. By H. Lauterpacht), International Law, $8^{\text {th }}$ Ed., Edinburgh.

Resolution III in Annex 1 to E/CN. 4/641 (Report of the Fourth Session of the SubCommission).

Seminar on Protection of the Human Rights of National, Ethnic and Other Minorities, Ohrid, Yugoslavia,25 June-8 July, 1974, (ST/TAO)HR/49) para 22.

Thornberry, P. (1980). International Law and the rights of Minorities, Oxford.

The Declaration is included in the Year Book on Human Rights for 1948, p.466

The Sub-Commission had in the beginning twelve and later eighteen members. In 1968 the membership was enlarged to twenty six. ECOSOC Resolution 1334(XLIV) May 31, 1968, which at the time laid down rules for the territorial distribution of membership in order to secure an appropriate representation of the "new" UN members: Afro-Asian Group of States 12, Western European and other States 6, Latin America 5, Eastern European States 3.

U N Document E/C N 4/367 Add, March 27, 1951

U N Document E/C N. 4/641. p. 32.

U N General Assembly Resolution, 24 (1)

U N. Document A/CN. A/CN. 4/A/C 1/3.

United Nations Document E/CN, 4/367 of April 7, 1950 and E/CN, 4/367 Add.1, March 27, 1951: Study of the legal validity by the Undertakings Concerning Minorities.

Year Book of the United Nations, 1946/1947, New York, 1947, p. 32 